\title{
Equity in science teacher education: toward an expanded definition
}

\author{
Brian S. Fortney ${ }^{1} \cdot$ Deb Morrison ${ }^{2} \cdot$ Alberto J. Rodriguez $^{3} \cdot$ Bhaskar Upadhyay $^{4}$
}

Received: 9 December 2018 / Accepted: 16 December 2018 / Published online: 25 May 2019

(c) Springer Nature B.V. 2019

In the current political environment in the USA, the purposes of science education (STEM education in general) have been touted as the panacea for better economic security and global dominance in these fields. This is supported by a neoliberal free market ideology based on individual responsibility for success (e.g., Hursh 2007). On the surface, the concept of "individual responsibility" sounds appealing, but its underbelly hides discriminatory practices, laws, history, and traditions. Thus, the expectation of individual responsibility without equity only permits dominant groups to easily shift the blame for the obstacles and struggles encountered by individuals from traditionally marginalized groups to their families and communities. Thus, overt and covert discriminatory practices continue by ignoring the historical, institutionalized, and social injustices suffered by marginalized groups then and now. In this light, the Editors of this Special Issue aimed to shift the focus on traditional notions of equity predicated by ahistorical and value-neutral conceptions of "success in science" by bringing attention to how white supremacy, colonialism, racism, ableism, and other forms of oppressions could possibly are perpetuated in our research and

Guest Editors: Brian Fortney, Deb Morrison, Alberto J. Rodriguez, and Bhaskar Upadhyay. The author names are in alphabetical order and contributed equally in the editorial.

This manuscript is part of the special issue Equity in Science Teacher Education: Toward an Expanded Definition, guest edited by Brian Fortney, Deb Morrison, Alberto J. Rodriguez, and Bhaskar Upadhyay.

Brian S. Fortney

Brian.Fortney@unt.edu

Deb Morrison

educator.deb@gmail.com

Alberto J. Rodriguez

rodri193@purdue.edu

Bhaskar Upadhyay

bhaskar@umn.edu

1 Teach North Texas, University of North Texas, Denton, TX, USA

2 Institute of Science and Math Education, College of Education, University of Washington, Seattle, WA, USA

3 Department of Curriculum and Instruction, College of Education, Purdue University, West Lafayette, USA

4 Curriculum and Instruction, University of Minnesota, Minneapolis, MN, USA 
teaching practices if we do not seek to reflect and act on what we really mean by the construct of equity in science education.

Equity is a term that everyone in science education-teachers, researchers, policymakers, principals, school administrators, curriculum developers, test makers, funding agencies, and science activists - seems to understand intuitively but all understand differently. While most educators with good intentions would broadly agree that equity is the path to access and successful participation of all students in science/STEM, in recent years, this term has become a blanket term with a multiplicity of taken-for-granted meanings (e.g., see Rodriguez and Morrison, this issue). For example, in many science learning settings, equity carries a more utilitarian meaning than a critical and questioning one when engaging students and families from underrepresented groups in science (e.g., Basile and Lopez 2015). Even a basic dictionary definition of the term provokes multiple questions. Take, for instance, Merriam-Webster's (2018) online dictionary definition of equity, "justice according to natural law or right; specifically, freedom from bias or favoritism." This definition of equity leads us to ask questions such as: What does justice mean in science education? What is natural law or right and for who? What is bias or favoritism in science education? These questions make us wonder if a unitary definition of equity is possible. On the other hand, if we believe that the meaning of equity is shaped by individual sociopolitical, sociocultural experiences and one's worldview, then how does the science education community work with a target that might be perceived as constantly shifting in its meaning across contexts and actions?

Given these challenges, the editors of this Special Issue felt an urgent need to instigate a conversation among science educators to reconceptualize and further explore what we mean by the construct of equity in our research and teaching practices. Therefore, we present herein ten manuscripts and eight forum responses in which scholars (from various sociocultural positionalities) tackle the construct of equity through diverse theoretical, methodological, geographical, and sociocultural lenses. We wanted scholars to take bold risks in what it meant to rethink equity and also encouraged collaborations between senior and emerging scholars as a way of enacting our own conceptions of equity praxis in science education. We believe that the marriage of ideas from senior and emerging scholars bring new ways of thinking about equity in science education. The coeditors also strongly believe that more critical and safer spaces are needed for emerging and new scholars if science education is to achieve its potential as a tool for social justice.

\section{Manuscripts included in this special issue}

Alberto J. Rodriguez and Deb Morrison's manuscript entitled, "Expanding and enacting transformative meanings of equity, diversity and social justice in science education" offer a critique of common uses of the term equity and how it is operationalized in science education research practice. They argue that there is a greater need to better define what we mean and how we enact equity so that we can be better positioned to incorporate a social justice agenda in our research and practice. They also argue that a sociotransformative approach to working for social justice allows to identify and disrupt power structures that could impede equity efforts, as well as create more effective opportunities for culturally and socially relevant science teaching and learning. A forum response by Monica L. Ridgeway extends the argument for social justice raised by Rodriguez and Morrison by offering a critical race 
analysis of Whiteness and why it is necessary to disrupt this framework if we wish to enact social justice in science education research.

Chantal Pouliot's autoethnography entitled "Speaking out about inequities" envisions equity through a relational lens between scholar activist and environmental activists. She places herself as the scholar ally of an environment activist that was in the midst of a legal battle with a powerful company in Quebec, Canada. A forum response by Jesse Bazzul and Sara Tolbert argues that in order for science educators to promote activist agendas, designed to empower communities, they need to value and support placed-based community knowledge and work side by side with community members to challenge powerful entities accustomed to put profit and privilege above the good of the community.

Kathleen Schenkel, Angela Calabrese Barton, Edna Tan, Christina Nazar, and Marcos Gonzalez's qualitative research entitled, "Framing equity through a closer examination of critical science agency" offer critical science agency (CSA) as a way to address issues of equity. They provide a vision of educational justice by more directly focusing on issues of power and political consciousness in science education praxis and research. Shirin Vossoughi and Molly Shea's forum response to the aforementioned paper examines several theoretical and methodological tensions evoked by the assumptions about agency and political consciousness the authors articulated in the context of working with traditionally marginalized youth.

Alaina Szostkowski and Bhaskar Upadhyay's theoretical paper entitled "Looking forward by looking back: Equity in science education as socially just and morally healing action" challenges science educators and researchers to consider equity from a moral and healing standpoint. If historical misuse of power by scientists and practitioners of science is any guide, then science educators should view equity as a moral imperative and healing as its outcome. They argue that without a morally guided stance to engage with in science, very little progress toward equity, social justice and social change-oriented agendas could be attained. They recognize the sociocultural variations between the Global South and the West both in the meaning of equity and morality and also the actions that would bring structural and personal meaning to learning science. Muhammad Abd Hadi Bunyamin's forum response extends the idea of morality and its connections to science education through the Islamic idea of zakah (giving material things including knowledge). He brings Malaysian and Muslim contexts in expanding the cultural value of giving knowledge as a moral act and how that act extends into science teaching and learning.

Alexis Patterson's manuscript entitled, "Equity in groupwork: The social process of creating justice in a science classroom" is an exploration of a culturally and linguistically diverse (CLD) classroom. She argues that the dialogic interactions in group work provide spaces for linguistically marginalized students to engage with and interact in science. The equity in science classrooms is explored through linguistic diversity and the nature of micro-interactions. Roberto Gómez Fernández's forum response expands on the significance of paying attention to the linguistic and cultural diversity in science classroom interaction by arguing that science teachers should learn more about the concept of translanguaging. Recognizing and promoting translanguaging in group interactions could lead to higher achievement and more equitable science classrooms.

Carolina C. Rodriguez, Laura Barraza, and Jenny Martin's qualitative study titled "Rethinking equity: standpoints emerging from a community project with victims of violence and abuse in Argentina" investigates how youths who have experienced violence make sense of science. They further juxtapose the case workers' and the researchers' reflections about what doing and knowing science mean to youths who have to live with violence, but need to learn science as well. Enrique Suárez's forum response to this 
paper takes the stance that partial fulfillment of equity agendas in science education should be looked at cautiously. He adds that researchers should avoid overextending claims of success in equitable science education and that we should all be prepared to fully explicate and support ways in which the root causes of the inequities being discussed are being addressed.

Priya Pugh, Megan McGinty, and Megan Bang's qualitative paper entitled, "Relational epistemologies in land-based learning environments: Reasoning about ecological systems and spatial indexing in motion" investigates the process of meaning making by Native youths in a summer program. They present a nature-culture relationship in which Native youths were engaged, as well as how Native cultural practices were used to know about the land and understand local environmental systems. They discuss what equity looks like from the Native youths' perspectives.

Angus Macfarlane, Richard Manning, Jamie Ataria, Sonja Macfarlane, Melissa Derby, and Te Hurinui Clarke's qualitative paper entitled, "Wetekia kia rere: The potential for place-conscious education approaches to reassure the Indigenization of science education in New Zealand settings" document how history, occupation by a foreign power, and racism have shaped science education experiences for Māori people. To this end, the paper uses a critical approach to examine how Māori indigenous people have been represented in historical and current policy documents in science education. Then, through the case study of a Pā Wānanga (Māori learning community), the authors show the value of place-based education to attain equity in science education in New Zealand for this indigenous group.

Brian Fortney and Erin D. Atwood's qualitative paper entitled, "Teaching with understanding while teaching for understanding" explores how an equity agenda in science teaching and learning evolves. He further argues that without evaluating the life experiences and contexts of interactions that students and teachers have gone through, the science education community will continuously face structural and political challenges to make science classrooms more equity oriented and socially just spaces. Daniel Morales-Doyle's forum response to this paper asserts that age-old idea of equity bounded by sociohistorical roots needs refocusing to bring change in science education. He further suggests that equity is only one aspect of the social justice agenda of science education. The goal of science education for equity should be about social change.

Phillip A. Boda's qualitative manuscript titled, "Conceptualizing the margins in science education: the limits of multicultural analyses" explores how graduate students' thinking shifts about disability in a university course. He further investigates how graduate students utilize classroom learning into their teaching and if the shift is more permanent. In other words, do graduate students reflect on the matters of equity and social justice when thinking and working with disability in science education contexts? Gina Tesoriero's forum response to the aforementioned paper suggests that asset-based pedagogies are key to bringing greater participation in science education from disability communities. She draws from her urban science educator experiences to further shift the equity agenda in favor of youths who come from various disability communities.

In these ten manuscripts and the eight forum reflections that accompany them, the construct of equity is critically examined from a multitude of lenses, including diverse demographic contexts, US and international settings, as well as different linguistic, cultural, socioeconomic, and theoretical frameworks. Inspired by Freire's (1970) always relevant call to praxis in education, we hope this Special Issue provokes reflection and discussion and promotes transformative action - the kind of transformative action that truly mirrors whatever chosen understanding of equity we invoke. 


\section{References}

Basile, V., \& Lopez, E. (2015). And still I see no changes: Enduring views of students of color in science and mathematics education policy reports. Science Education, 99, 519-548. https://doi.org/10.1002/ sce. 21156.

Freire, P. (1970). Pedagogy of the Oppressed (trans: Ramos, M.B.). New York: Bloomsbury.

Hursh, D. (2007). Assessing No Child Left Behind and the rise of neoliberal education policies. American Educational Research Journal, 44, 493-518. https://doi.org/10.3102/0002831207306764.

Merriam Webster Dictionary (2018). Equity. Retrieved on November, 2018, from https://www.merriamwebster.com/dictionary/equity.

Publisher's Note Springer Nature remains neutral with regard to jurisdictional claims in published maps and institutional affiliations. 